\title{
WYCHOWANIE RODZINNE DZIEWCZĄT W PEDAGOGICE ŚW. HIERONIMA
}

Poruszajac problematyke starozytnej rodziny 1 wychowania nie sposób pominąć św.Hieronima z jego pryncypiami wychowawczymi. Nie napisaz on wprawdzie specjalnego traktatu o wychowaniu dzieci, Jak to na Wschodzie uczynił św.Jan Chryzostom lub na Zachodzie współczesny Hieronimowi św. Augustyn ${ }^{1}$, ale jest chyba jedynym wczesnochrześcijańskim pisarzem, który swej twórczości przekazal potomnym sume uwag na temat początkowego wychowania dziewcząt ${ }^{2}$. Swoje założenia pedagogiczne, przejete w duzej mierze od Kwintyliana ${ }^{3}$,

1 Joannes Chrysostomus, De inani gloria et liberis educandis, SCh 188, tłum.W.Kania, PSP 13,153-185; August1nus, De catechisand1s rudibus, CCL 46,121-178, tłum. W.Budzik, POK 10,3-71.

2 Por. C.Ernesti, Hieronymus Brier an Lata und an Gaudentius, Paderborn 1889; J.Brunner, Der hl.H1eronymus und die Madchenerziehung auf Grund seiner Briefe an Laeta und Gaudent1us. Eine patrist18ch-pldagog1sche Studie, Mttnchen 1910; D. Gorge, La lettera a Leta o delloducazione della figliuola, Modena 1932; Ch. Favez, Salnt Jérome pédagogue, In: Mélanges de philologie, de litterature et d'histolre anciennes offerts a J.Marouzeau, Paris 1928, 173-181; P. Labanca, Ideo pedagegiche di S.Girolamo, M1 lano 1901; J.Turmel, Saint Jerome; Paris 1906, 52-56/= L'éducation des 111ies/; F.Cazes, St.Jéróme et la lecture des livres saints, Gaud 1921; R.P.Largent, Saint Jérôme, Par1s 1922, 84-96/= 1'éducateur/; L. Ventura, La pedagogia del Cristianesimo, vol. 1: Le origini e la patristica, F1renze 1924, 132-154; A.Bardicch1a, Il pensiero morale e pedagogico di S.ülrolamo, Materna 1925: G.Gorgo, Les dames romalnes a l'école de Salnt Jórome. Paris 1928; J.D'Irray, Saint Jerome et les dames de l'Arentin Paris 1937; A.Penna, S.Girolamo, Tor1no 1949, 75-92; J.C8uj, Sw.H1oron1m, zywot-dz1 elo-charakt orystyka, Farszawa 1954, 75-78; L.Leopoldus, Insognament 1 ascetc1 nollo lottero d1 S.G1rolaso, Nocora Super1ore 1967; H.Scholl, Das B1ldungsproblem in dor Alten K1rcho, 1n: Frziohung und Bildung in der heidnischen und christilchen Ant1ke, hrsg. T.J.Horst, Darmstadt 1976, 522-526.

3 Instrtut10 orator1a, tzum. M.Brozek, Kaztalconio móncy, Ks.1, II,X, Wrockaw 1951; por. A.Danysz. Toorya pedagoglezna Kwintyliana, "Eos" 5/1899/ 169-186; V.Alfiert, La pedagog1e di Quint1liano. "Atonaeum" 42/1964/400-415. 
zamarł przode wszystrim dwóch listach przesłanych z Betlejem do izymu: dzuzszym,z 403 r., do Lety o pychowantu makej "poswięconej

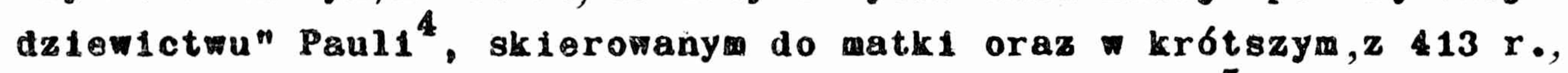
do Gaudoncjugzo o wychowantu jego córeczk1 Pakatul ${ }^{5}$.

Choclaz zawarte nich wakazania pedagogiczno odnosizy sie przede wszystkim do dziewczat przeznaczonych do stanu dziew1czego ${ }^{6}$, to jodnak wakania to ze wgledu na swa uniworsalnośc mozna było rykorzystac do poczatkomego chrześcijańskiego pychowywanta dziewcząi ogóle. Pełną sumę uwag ascetyczno-pedagogicznych na temat pielegnomania dziowictwa przeszal już wezesniej $384 \mathrm{r}$. Iiscie do Eustochi ${ }^{7}$, ale byly one przeznaczone dla dorosłej dziewczyny przebywajacej klasztorzo. To Hieronimowe zainteresowania dziewczecym 1 koblecym wychowaniom yyodza sie z czasow, kiedy to w latach 382-385 przehymaz Hzyme 1 nawiazal szereg przyjaznych stosunkó z k11koma fysoko urodzonymi niowiastami, którym póńniej listach przesyłal duchowe mskazówk1. Jego pouczenta pedagogiczne miały ukształtowac pełnego chrześcijanina, bo jak twierdzit: "Fiunt, non nascuntur Christiani"/Chrześcijanie się staja, a nie rodza/ 8 .

Fizystkie uwagi pedagogiczne, zawarte wyzej wymienionych listach, zgrupujemy wokó trzech zagadnien: mychowawców, wychomania intelektualnego oraz moral no-ascetycznego.

\section{Wychowawcy}

Podobnie, jak większość starozytnych pedagogów pogańsk $1 \mathrm{ch}$ i chrześcijańskich Doktor ze Strydonu zracal umage na konieczność doboru mzorowych i religijnych wychoma cón odpowiodnich dla wieku

4 Epistola 107/Ad Laetam de Institutione P111ae/, CSEL 55, 290-305, tium.J.Czuj/Sw. Hieronim, Listy, t.1-3, Warszawa 1952-1954/t.2, 400-414.

5 Epistola 128 /Ad Gaudentium de Pacatulae infantulae educatione/, CSEL 56, 156-162, Czuj t.3, 286-293.

6 Ad Laetam 3, CSEL 55, 293, CzuJ t.2, 402-403: ".. powzlatem zamiar skierować swoje słoma do matki, to jest do ciebie, 1 pouczyć clę, waki spósób powinnaś mychowywać nasze paulę, która plerwej była poświ gcona Chrystusowi, niz zrodıona, któri wcześniej pośrię-ciłaś, niz pocż̨aś".

7 Epistola 22 /ad Eustochium/, CSEL 54, 143-211, Czuj t.1, 110-162.

8 Ad Laetam 1, CSLl, 55, 291, C $z$ uj t.2, 401. 
dziecka. Oni to obok rodziców "winni kształtować duszę dziecka, która ma być świ atynia Pana" " Należeli do nich nie tylko nauczyciele, lecz także niańki i opiekunki. Źąda od nich wysokich kwailrikacjl moralnych, takich jak żywa wiara, nienaganne obyczaje, powaga ! powści tzgliwość w llowie, które stanz się rękojmia urabiania umysłu dziewczecego w cnocie. Ponalto osoby te winny wyróżniać sie zdolnościa prowadzenia zajz̨ć praktycznycin, aby umiejętności swe przekazywać dziewczynce od lat najwčeśniejszych.

"Opiekz nad niz trzeba powierzyć doświadczonej kobiecie o wypróbowanej wierze, obyczajach 1 wstydliwości, żeby ja uczyła i przykładem przyzwyczajała do modlitwy 10 , "Niech też niańka nie będzie pijaczka ani rozpustnicą, ani plotkarką, niech ma skromni nosicielke, wychowawce poważnego"11.

"Nauczyciela należy wybrać godnego-wiekiem, życiem, wykształceniem 12 . . cielka, opiekunka wychowawczyni, nie za bardzo lubiaca wino, nie próżnująca i gadatliwa, lecz trzeźwa, powaźna, która zna sztukę przżzenia"13.

Główna odpowiedzialność za wychowanie dzieci spoczywa jednak na rodzicach $i$ najbliższych członkach rodziny. Hieronim, podobnie jak nieco wcześniej Jan Chryzostom ${ }^{14}$, podkreślał tu bardzo ważny problem konieczności odpowiedniego klimatu rodzinnego do prawidłowego rozwoju psychicznego 1 osobowego dziecka, niemal caikomicie pominięty przez Kwintyliana. W szczególny sposób wskazywał na potrzebę radości 1 pogody, ciepła, czułości i pieszczot ze strony nie tylko rodziców, lecz takze najbliźszej rodziny, z która dziecko winno się zapoznać 1 ż̀yć od wczesnego dzieciństwa. Na te elementy

9 Tarze 4, CSEL 55,293, Czuj t.2,403.

10 Tamże 9, CSEL 55,300, Czuj t.2,410.

11 Tamże 4, CSEL 55,295, Czuj t.2,405; por. Quintilianus I, 1,4, Brozek 16: "niech niańki mówia poprawnym jegzykiem ... w pierwszym rzędzie winna tu decydować ponad wzelka watpliwość jakość obyczajów. Jednakze 1 język $1 \mathrm{ch}$ powinien być także poprawny".

12. Tamze 4, CSEL 55,294-295, Czuj t.2, 404-405; por. Quint11ianus, I, 1,8, Brożek 18: "... musza mieć nalezyte vykształcenie".

13 Ad Gaudentium 4, CSEL 56,160, Czuj t.3,291.

14 Por. De inant glorta 16, 22-23, SCh 188, 96-100, 106-110, PSP 13, 163-165. 
atmosfery rodzinnej zwraca równiez uwage współczesna psychologia, uznając, iź saz one jedniz z podstawowych potrzeb dzlecka, gdyż zapewniaja mu poczucte bezpieczeństwa. Na rodzicach, jak ong1ś na Helim/1Krl 2,27/, ciąży odpowiedzialność za postępowante dzieci, niezaleznie od ich wieku, a zwłaszcza za małe 1 słabe, poniewaz -

\footnotetext{
"nle zdaja sobie sprawy z róznicy między dobrem a złem! Kto jednak jest dzieckiem i rozumuje jak dziecko, tego zarówo złe, jak 1 dobre uczynk1, dopók1 nie dojdzie do wieku rozumnego/.../ 1da na rachunek rodziców"15.
}

Odpowiedzialność za wychowanie dziecka jest jeszcze większa, Jezel1 rodzice podjęli decyzję, zwłaszcza na mocy ślubu, oddać córkę na słuzbę Bogu. Brak należytego wychowania takiego dziocka Hieronim nie waha sie nazwać nawet świętokradztwem ${ }^{16}$. W wyadku śmierci jednego z rodziców, szczególnie ojca, zachęca matkę, by nie zawierała powtórnego zwizzku małzeńskiego, a poświeciła się wyłazcznte wychowywaniu dziec1, co zrekompensuje jej miłość do utraconego $\operatorname{meza} \mathbf{a}^{17}$.

Rodziców, jako plerwszych wychowawców, winna cechować wzajemna miłość 1 miłośc do dzieci, dobroć, lagodność. Maja oni promadzić worowe zycie, bo jak głosi starozytna maksyma słowa ucza, a przykiady pociagaja. Hieronim, powołujac sie na Kwintyliana, przypomina matke Grakchów i ojca Hortensjusza, którzy wywarli na synów przez swój przykład wpływ decydujący. W wychowaniu dzıewczynk 1 szczególna rolę odgryma jednak wzór matki:

15 Ad Laotam 6, CSEL 55,297, CzuJ t.2, 406-407.

16 Tamze 6, CSEL 56,298, Czuj $t .2,407$ : "orlarować córke albo Jej nie ofiarowac w trojej by 10 mocy ... Zantedbymanie jednak orlarowanej grozi cl Juz niebezpleczeństmom. Kto by złozyz oflare kulawa, okaleczona lub jakimkolwlek brudem splamiona, minien jost ślętokradztwa".

17 Epistola 79,7 /Ad Salvinam/, CSEL 55,94, Czuj t.2,217: "Masz więc, Salwino, dzleci, które powinnaś wychowywać 1 mozesz być przekonana, te ci zastapia nieobecnego maxzonka./.../ Za jednego czlowioka otrzymalas dwoje dzieci; zwigkzyla gle $11 \mathrm{czba}$ ukochanych. Oddaj dzieciom to, co powinnaś byla dać małzonkow1. Niechaj miłó́ć obecnych ukol tęsknotę za nieobecnym". 
"Cleble ntech ma za nauczycielke, cieble niech nasiaajo jej dziecięca prostoduszność. Niech w tobie 1 ojeu gwoim nie widzi nic takiego, przez wykonanie czego popelnilaby grzech. Pamietajeie wy, rodzice, o dziewicy; pamietajcie, że wiecej mozna ja nauczyć przykładani, n1z słowari"18. "Niech skintenie matk1 ma za słowa, za napomnienie, za rozkaz. Niech ja kocha jako rodzicielkę, niech jej poddana będzie jako pani, niech s1e bol jak nauczyciolk1"19.

Podobnie, jak dziś, w procesie wychowawczym nieoceniona role pełnia babcie 1 dzladkowie oraz inni członkowie rodziny. MaJa oni uczestniczyć zabawach dziecka 1 otoczyć je troskliwa pleszczotą:

"Gdy zobaczy dziadka, niech skacze na jego piersi, chwyta za szyję, niech mimo woli śpiewa "Alleluja". Niech ja bierze na roce babka/.../ Niech siz zaraz dowie, jaka ma druga babkę, jaka ciotke $20 / \ldots /$ Niech przebywa na lonte babki, która we wnuczce będzie szukać cech, jakie dawniej zaszczeplła córce, która w długiej praktyce nauczyła sie wychowywać, pielęgnować 1 nauczaénz1.

Rodzinna atmosfera jest wį̧c najlepszz kolebka wychowania, bo "święty 1 wierny dom uświęca jednego niewiernego. Już jest kandydatem wiary ten, którego otacza tłum wierzących synów 1 wnuków"22.

Proponowane ogólne założenia wychowawcze Hieronima mają dwa aspekty: negatywny - chronić za wszelką cenę dzieci przed źródłem $z^{23} a^{23}$ co wyraźa się w szeregu określonych zakazów oraz pozytywny -

18 Ad Laetam 9 i 4, CSEL 55,300 i 299, Czuj t.2,409 i 405; por. epistola $82,3 / A d$ Theophilum/, CSEL 55, 110-111, Czuj t.2, 231232: "Ojciec bowien winien kochá́. Ojciec 1 biskup powinni mzbuazać milość, nie lęk./.../ dobrzy rodzice powinni się starać, by nie pobudzać do gniewu synów swoich, 1 zbytkiem surowości nie doprowadzać do sxogości nawet bardzo ragodnych"; Quintilianus $I, 1,6$, Brozek 17 .

19 Ad Gaudentium 4, CSEL 56,160, Czuj t.3,290; tamże 1, CSEL 56, 157, Czuj t.3,287: "niech zawiśnie u matczynej szyi, niech porywa pocałunki bliskich".

20 Ad Laetam 4, CSEL 55, 295-296, Czuj t.2,405.

21 Tamze 13, CSEL 55,304, Czuj, t.2,413.

22 Tanze 1, CSEL 55,291, Czuj t.2,401.

23 Por. Ad Laetain 6, CSEL 55,297, Czuj t.2, 406-407: "Pilnie dbasz o to, by córk1 nie napadła źlíja; dlaczegóz z taká saniz troskliwościl nie miatabys dbać, by nie uderzyl jej młot wszystkiej 
zło dobrem zwyciézać ${ }^{24}$. Te dwie zasady przejawiać się będą we

mszystich wypowiedziach Hieronima na temat wychowania.

Z konkretnych wskazaí zaleca on wyrabianie od poczatku u dziecka posłuszeństwa, które ma wynikać nie z przynusu i bojaźni, lecz z miłości l szacunku dla rodziców, unikanie zbyt surowego, zniecḩ̨cajzcego karcenia oraz stosowanie pochwał i nagród jako środka wychowawczego:

\begin{abstract}
"Nie należy jej karcić, jeśli będzie trochę opieszała, lecz pochwałami podniecać zdolności, żeby zarówno cieszyła sie z sukcesów, jak i cierpiała z powodu niepowodzeń"25. "Należy jej w nagrodę ob1ecywać ciasteczka miodowe i inne smakołyki, wszystko, co jest piękne jak kwiaty, co błyszczy od klejnotów, co jej się podoba w lalkach; niech usiłuje to otrzymać"26 ... trzeba ja zachęcać podarkami, które w jej wieku sprawiaja uciechę" 27 .
\end{abstract}

\title{
2. Wychowanie intelektualne
}

Hychowanie intelektualne dziewczat, zdaniem Ascety z Betlejem, winno przebiegaé podobnie jak wychowanie chłopców. Z jednej strony

ziemi /Jer $50,23 /$, by nie pijała ze złotego kielicha Babilonu" /Jer 51,7/; Epistola 79,10, CSEL 55,99, Czuj t.2,222: $" / \ldots /$ abyś wiedziała, że jesteś człowlekiem i że ulegniesz słabości ludzkiej, jeżeli nie będziesz się miała na baczności. Wszyscy jesteśmy zrobieni z tej samej gliny i złozeni z tych samych plermiastków; i wedwabiu, i w prostym stroju panuje ta sama zadza. Nie ląka się ona purpury królewskiej i nie gardzi łachmanem żebraczym, 1 o wiele lepiej, byś miala chory żoładek niź chora duszę, lepiej rozkazywać ciału niż mu słuzyć/.../ Należy strzec się rany, którz się leczy bólem".

24 Por. Epistola 125,14/Ad ilusticum monachum/, CSEL 56,132-133, Czujt.3, 263-264: "Filozofowie świeccy mają zwyczaj stara miłość usuwać nowya uczuciem, tak jakby klin klinem/por. Cicero, Tusculanae disputationes $4,35 / \ldots$ Tamc1 występek lecza wystzpkiem i grzech grzechem, a my miłością do cnót zwyclężamy występki. Prorok mów1: "Odwróć się od złego, a czyń dobrze, szukaj pokoju i ubiegaj sle za nim" /Ps 33,15/. Jeśli nie znienawidziliśmy złego, nie możeny kochać dobrego. Nalezy wįc czynić dobro, abyśny odwrócili się od złego; nalezy szukać pokoju, abyśmy uniknęli wojen".

25 Ad Laetam 4, CSEL 55,294, Czuj t.2,404.

26 Ad Gaudentiuta 1, CSEL 56,157, Czuj t.3,287.

27 Ad Laetam 4, CSEL 55,294, Czuj t.2,404; por. Quintilianus I, 1,20, Brożek 21: "trzeba dziecko zach cać do niej i prośbł, i pochwała, a przy tym sprawiá mu te radośc, ze zawsize umiało. 
trzymaz sie on zasad Krintyliana, z drugiej zaś szedł wasna drogą, właczajac do ogólnych zasad starożytnego wychowania treści chrześcijańskie. Wyrózniał w nim za Kwintylianem dwa okresy: dc 7 roku życia oraz od 8 do 12-15 roku. Zdawaz on sobie doskonale sprawę, jak trudno jest trafić 1 przemówić do mentalności dz1emczynki, szczególnie przed 7 rokiem życia, "która nie rozumie co mówisz; nie znasz jej umysłu, a o jej pragnieniach czynisz niepewne obietnice 28 . Mimo wszystko początkowej razie wychowywanla Intelektualnego rodzice troszczyć sie maja szczególnie o poprawność 1 plękno mowy oraz naukę czytania i pisania. Matce przypomina, zeby uwazała, aby córka nie przyzwyczaiła się mówić półsłówkami, gdyz "z trudem daje sie wykorzentc to, czym nasiakz młody umysz"29. Poprawność języka dziecka uzaleznial równtez w duzym stopniu od poziomu wykształcenia 1 jezyka wychowawcy, poniewaz "dźwięk liter 1 plerwoze wskazómi nauczyciela inaczej brzmia w ustach ludzi wykształconych, a Inaczej w ustach prostaczkóm30. Im więc kultura nauczającego jest wyzsza, tym lepsza poprawność mowy.

Przy nauce czytania, zgodnie zasadami starozytnymi, zalecal najplerw pamieclowe opanowante alfabetu oraz posługivanie sie literaml wykonanymi z bukszpanu lub kości słontowej, w colu umotliwienia dziewczynce poznania lch nle tylko z brzmienia, ale 1 a wygladu, a następnie zaczenta $1 \mathrm{ch}$, sylaby 1 przestawiania kolejności 11 ter 31 .

/... / trzeba ma takze dodawać bodźca do tej nauk1 przez odpow1ednie do jego wieku nagrody"。

28 Ad Gaudentium 1, CSEL 56,156, Czuj t.3, 286-287: "Jak bow1em bẹdziesz zachęcat do powśclagliwośc1 tę, która pragnie ciastek, która na conie matki szczebioce pieszczotilie, dla której słodszy jest miód niz słowa? Czy moze słuchać głęokich słów Apostoła ta, której więsza przyjeinność sprawiaja bajeczki starych niowlast? Czy moze zrozumieć aentgmata - zagadk1 Proroków ta, która niepokol smutne oblicze niani? Czy moze pojać majestat Ewangeli1 ona, u której na głos płoruna topnieja wszystkie zmysły ludz$\mathrm{k} 1 \mathrm{e}$ "?

29 Ad Laetam 4, CSEL 55,295, CzuJ t.2,405.

30 Tamze.

31 Ad Laetam 4, CSEL 55,294, Czuj t.2,404: "Nalezy jej sporzadzić litery albo z bukszpanu, albo z kośc1 słonlowej 1 zapoznać z $1 \mathrm{ch}$ nazwami. Niech sie bawi ntmi, aby i zabawa była jej nauka. Powinna nie tylko zapamietać porzadek liter i umieć na pamiéc lch nazwy jak piosenke, ale trzeba tez często porzadek 1ch zmieniac 1 środkowe laczyć z ostatnimi, a pierwsze ze środkowymi, by je 
To pierwsze nauczanie ma więc przede wszystkim charakter poglądowy, polegajłcy na wyrabianiu u dziecka panięci l zdolnoścl kojarzenia.

W pierwszych 7 latach zycia dziecko, obok nauki czytania, winno równiez poznać sztukę pisania. IIieronim i tej dziedzinie proponował stara metodą rzywsk która wauce pisania zalecała uźywanie tablic woskowych ${ }^{32}$ :
"Gdy /dziecko/ zacznie drżącaz ręką wodzić rylec po mosku, niech cudza ręka kieruje delikatnymi paluszkami dziecka: albo tez wyryć trzeba na tablicy litery, aby mogło ono pociagać rylec ściśle po tych śladach"33.

Po pamięclowym opanowaniu liter alfabetu, dziecko starozytno pod kierunkiem nauczyciela uczyło się łaczyé je w wyazy. Składało je najczęściej Imiona znane z mitologii lub historil rzymskiej, co było pozyteczne późniejszej jego formacji intelektualnej. Hieronim mając na uwadze wychowywanie dziecka chrześcijańskiego, od początku zalecał wpajać mie religijne treśc1 chrześcijańskie, a zamiast pogańskich uczyé imion biblijnych:
"Imiona, na których będzie sie przyzwyczajać do składania słów, rómieź nłe moga być przypadkowe; powinny to byé imiona określone 1 z rozmysłem dobra- ne, mianowicie imiona proroków i apostołów; powinien się też śród nici znaleźć katalog imion Patriarchów od Adama poczynajłc - według Mateusza i Lukasza. W ten sposób co innego czyniac, pozostanie on już painięci na przysztośćnł.

Od początku równiez Rzymianie, zaledwie dziecko zaczęło mówić, wyrabiali u niego pamięć przez mechaniczne uczenie wierszy, piosenek lub fragmentów poezji rzymskiej. Hieronim natomiast zalecał dziewczyn-

poznawała nie tylko z brzmienia, ale takze 1 z wylgąu"; Ad Gaudentium 1, CSIL 56,157, Czuj t.3,287: "Niech poznaje literki, niech łaczy głoski, niech się uczy wyrazów, niech wiaze słowa".

32 Por. Quintilianus, Institutio oratoria I, 2, 26-27, Brożek 23-24; J.Carcopino, Życie codzienne w Rzymie wokresie rozkwit." nosarstwa, Warszawa 1966, 111-112.

33 Ad Laetam 4, CSEL 55,294, Czuj t.2,404; Quintilianus I, 1,25-28, Brożek 23: "Kiedy zaś chłopiec zacznie już naukę pisania, nie be poźytku to będzie, jeżli wyryje mu sie litery jak najstaranniej na twardej tabliczce, aby po tych jak gdyby po bruzdach uczyl sie prowadzić rylcem".

34 Tamże, CSEL 55,294, Czuj t.2,404; por. Quintilianus I, 1,34-36, 
kom uczenie sle na pamięć wyjątków z pałterza:

"Niech sie najpierw uczy Psazterza 1 niech znajduje rozrywke tych plośntach" ... "Niech nie zna pleśnt świeckich, język nlech od młodośc1 nasyca slę słodycza psalmówi35.

To pamieciowe opanowanie imion biblifnych 1 psalmó stanowi plerwszy etap Intelektualnego wychowanta chrześcijańskiego.

Hieronim zdaje sobie jednak doskonale sprawe z faktu, iz zbytnie wymagania moga spowodować odwrotny skutek. A tego - jak zaznacza - "trzeba sie strzec, zeby /dziewczynka/ nie znienawidzila nauki, zeby wstret do niej, zaszczepiony dzieciństwio, nie pozostal po latach dzlectegcych"36.

Dzlewczynka według Hieronima "niech kocha to, czego musi się uczyć, aby nie było to dla niej praca, lecz przyjemnością" ${ }^{37}$. Dlatego tez nauczanie w poczatkowej fazie traktowane jest jako zabawa, na co równiez zwraca uwage współczesna psychologia, podkreślajac, 1z jest to 1stotny składnik właściwego rozwoju dziecka. Hieronim wskazujac takżo na konieczność zdrowej rywallzacji między dziowczynkami, gdyz sprzyja ona 1 nauce 1 zabawie, preferuje nauczanie zbi or owe :

"Niech ma nauce towarzyszki, którym by zazdrościła, których sława niepokoilaby $\mathrm{ja}^{38}$... Jeśli pytasz o coś z Pisma śr., pytaj publicznio; pjech słysza słuzace, niech słyszą twoje towarzyszki"39.

Obok zaję intelektualnych Hieronim proponował przyzwyczajać dziewczynke do bardzo prostych prac ręcznych:

Brożek 25-26.

35 Tamże 12 i 4, CSEL 55,302 1 294, Czuj t.2,411 1 403; Ad Gaudent1um 1 i 4, CSEL 56,157 1 160, Czuj t.3,287 i 290: "Niech za nagroda śpiewa Psalmy" ... "Niech się uczy na pamięć Psatterza".

36 Ad Laetam 4, CSk̇L 55,294, Czuj t.2,404 por. Quintilianus I, 1,20, Brozek 21.

37 Ad Gaudentium 1, CSEL 56,157, Czuj t.3,287.

38 Ad Laetam 4, CSEL 55,294, Czuj t.2,404; por. A.Quacquarelli, Scuola e cultura dei primi secoli cristiani, Rrescia 1974, 37 .

39 Ad Gaudentiua 3, CSEL 56,159, Czuj t.3,290. 


\begin{abstract}
"N1ech próbuje delikatnymi paluszkami rozclagać nici, niech teraz często targa przędze, zeby jej kiedvś nie targałan40.
\end{abstract}

N1e są to oczywiście zajęcia w ścisłym znaczeniu, ale raczej dziecięca zabawa w pracę,którą póńniej jako dorosła kobieta będzie wykonywac 41 .

Powyższe umiejątności mpajane dziecku przed 7 rokiem zycia miały, zdaniem Hieronima, stanowic przygotowanie do drugiej lazy formacj1 intelektualnej, która odpowiadała masadzie czasowi szkoły elementarnej ${ }^{42}$. Przygląając się programow1 rzymskiej szkoły podstawowej zauważymy, że Hieronim wiele z jego punktów, jak pisanie i czytanie zalecał uczyć już wczé́niej w domu, przed 7 rokiem, idąc za Kwintylianem 1 pedagogami,głoszącymi, ze "żaden okres życia nie powinien być wolny od pracy"43. Chociaż dziewczynki uczęszczały, jak sie zdaje 44 , do szkoły podstawowej na równi z chłopcami, to jednak dla dzieci ze sfer wyżsyych, szczególnie dziewczizt, zalecano jeszczo do końca IV wieku naukę i wychowanie domowe. Od dawna bowiem trwała nie rozstrzygnięta dyskusja, czy posyłać dzieci do szkoł publicznych, czy teź wychowywać je w domu? Kwintylian by goracym zwolennikiem szkoly, twierdzac, że ona lepiej przygotowuje dzleci do zycia społecznego ${ }^{45}$. Zwolennicy wychowania domowego argumentowali natomiast, że szkoła publiczna, kształcaca dzieci z róźnych rodzin, o zróznicowanym poziomie moralnym, moze wpływać demoralizujaco na dzieci wychowywane w duchu wzniosłych zasad etycznych. Wykazymali również, że uczeń, majacy do dyspozycji nauczyciela prywatnego, rozwija sie zracznie szybciej 1 wszecinstronniej, ponteważ cała uwaga wycilowawcy skunia sie wyłacznie na nim, na jego ujennych $i$ dodatuch cechach charakteru. Hieronim opowiedziaz się także zá tat drugaz tendencjz - domowym wychowanien $i$ naukz pod

40 Tamze 1, CSLL 56,157, Czuj t.3,287.

41 At Laetam 4, CSIL 55,294, Cr!!j t.2,404.

42 Por. Quintilianus I, 1,15-18, Brozek 20-21; iI.J.Marrou, Historia wychowania w starożytności, liarszawa 1969, $373 \mathrm{nn}$.

43 quintilianus $I, 1,15$, 3roziek 20 .

44 Por. Martialis, Lpingamata IX, 68,2.

45 Por. (uintilianus I, 2, Brozek 26-35; l'linius, Epistola IlI, 3,3; Paulinus Pelleus / + 459/, Lucinalisticon 60 nn, ĆSEL 16, 1 , 291; II.J.Marrou, ilistoria wychowania, Warszawa 1969, 374. 
kierunkiem prywatnego nauczyciela, tym bardziej, ze Paula i Pakatula wywodziły sia z arystokritycznych rodów. Sam zresztá nigdzie nie wspomina o posylaniu dzieci do jublicznej szkoty elementarnej. Do programu podstawowego nauczania domowego włzczał jednak, jak zobaczymy, szereg elementów ze szkoły średniej. Szczególny nacisk kładł zwłaszcza na zaznajolilenie dziecka z Pismen św., z którego, jak ze skarbnicy, ma ono czerpać przykłady moralne. Zalecał, by skalę trudności dostosowywać do rozwoju i wieku dziecka. Po opanowaniu sztuki pisania i czytania nauka winna być kontynuowana wostaci éwiczeń, aby w ten sposób pogłębić znajomość ojczystej łaciny -

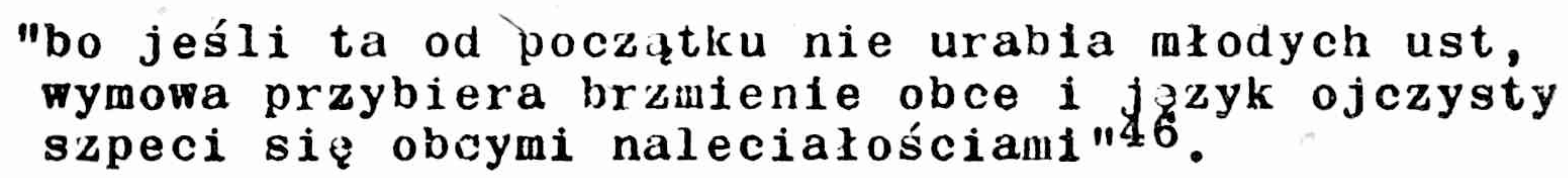

a także nauke Języka obcego - greki, która miała otworzyć bramy, zanikającej, ale pielęgnowanej szczególnie przez wyższe sfery arystokratyczne, kulturze Hellady.

Nauka greckiej metryki, pozwalajacej na lekture greckich poetów, należała już do programu szkoły średniej, do zadań gramatyka, który przerabiał z uczniami autorów klasycznych; zalecana zaś dbałość o czystość i poprawność języka miała chronić mowę arystokratycznego dziecka przed silnymi w tym czasie w Rzyie prowincjonalizmami. Znajomość tych języków miała również zapewnić dostęp do lektury autorów chrześcijańskich. Wykształcenie starożytne, przygotowujuce młodego obywatela do życia publicznego, opierało się na gramatyce połazczonej z lektura autorów klasycznych, retoryce - uczacej przemawiać, i dialektyce - uczacej rozumować. W omawianych listach Hieronim nie wspomina o tych dyscyplinach, gdyz były one zbyteczne dla dziewczynki przygotowywanej do klasztoru, a nawet szkodliwe, zwaźywsy na pełną erotycznych mątków, nierzadko o rozwiazłej treści, literature klasyczną. Stąd to wyłączy z nauczania dla dziewcząt cała literature narodowa, mimo 1z zezwalał Ja czytać $i$ metlejem prowadziz jej kursy z chłopcami.

46 Ad Laetam 9, CSEL 55,300, Czuj t.2,409; por. Quint 11 ianus I, $1,12-13$. 
Choć wiec z jednej strony, zgodnie z trwającym jeszcze wówczas chrześcijańskim nastawieniem, uważał, ze "pokarmein demonów są p1eś.. ni poetów, mądrośs światowa, napuszone słowa retórów", to z drugiej zaś byz przekonany, że korzystanie z nich jest niezbędne $i$ konieczne dla młodzieźy męskiej welu zdobycia ogólnego wykształcenia ${ }^{47}$. Zamlast beletrystycznych watków, pełnych scen erotycznych z mitologi1, I kształcenia retorycznego proponowal lekture 1 systematyczne wyjaśnianie Pisma św. Starego i Nowego Testamentu oraz pism niektórych autoróm chrześcijańskich. Biblijne opowieści miały wyprzeć mity, a śpior psalıów I Alleluja - pogańskie piosenki dziecięce.

Zapoznawanie jednak dziewczynki z Pismem św., jeżeli ma osiagnąć zamierzony skutek, musi się odbywá́ według ścísle określonego schematu. Najpierw ma síz ona, jak już wspomniano, uczyć na pamięć psalmów. W druglej kolejności miały iść księgi Starego Testamentu o charakterze moralno-ascetycznym: ucząca życiowej mądrośc1 - ksiega Przypowieści Salomona, pogardy dla rzeczy doczesnych - księga Eklezjastesa, a męstwa 1 cierpliwości - księga Joba. Następny etap - to zaznajamianie dziecka $z$ pismami Nowego Testamentu: Ewangeliami, Dziełami Apostolskimi 1 Listami Apostołów, obok których nie wymienia jednak, być moze ze wględu na trudną treść, księg1 Apokalipsy. Dopiero po takiej formacji intelektualnej zaleca czytanie biblijnych ksiag historycznych 1 prorockich: Pięcloksięgu, Ksiag Królewskich, Kronik, Ezdrasza, Estery 1 innych proroków. Na końcu zaś, gdy dziewczynka będzie w stanie zrozumieć jej duchowy sens - ksiege Pieśni nad Pieśniami 48 .

Powyzszy program nauczania biblijnego, poniewaź by bardzo obszerny 1 niewątpliwie trudny do zrealizowania samym tylko wieku dziecięcym, nawet wajidealniejszych warunkach domu arystokratycznego, musiał być zapewne realizowany $i$ w póniejszych latach młodzleńczych, na co zdajá sie wskazywać słowa: "aż do lat dojrza-

47 Epistola 21,13/Ad Damasum/, CSEL 54,122 i 124, Czuj t.1,93 194.

48 Ad Laetam 12, CSEL 55, 302-303, Czuj t.2,411-412: "Niech sie najpierw uczy Psałterza i niech znajduje rozrywk niach, a na Przypowieściach Salomona, niech się przygotowuje do zycia. Niech z pomocz Eklezjastesa przyzwyczaja się deptać rzeczy tego świata. W księdze Joba niech szuka przykładów męstwa i cierpliwości. Niech potem przejdzie do Ewangelii, zeby juz nigdy nie wypuszczać ich z ręki; Dzieje Apostolskie 1 Listy niech z zapałem wchłania całym sercem. Gdy tyini zapasa- 
łości"/usque ad annos pubertatis/49. Mieronim proponował więc bezpośrednie przejście od elementarnej nauki czytania i pisania do lektury Pisma św. - do bezpośredniego zetknięcia się ze źródłem objawienia. Mimo, że Juź w tym czasie ukończył większość swoich komentarzy biblijnych, nie zalecał dziecku żadnego z nich. Martwiz litere komentarza miał zastzpić żywy komentator w osobie rodziców i wychowawców. Wyrocznia biblijną miał byé dla dziecka dom i rodzina. Latwo zauważyć, ze nakreślony przez Ascetę z Betlejem program studium Pisma św. zapewniał dziecku nie tylko pewnz sume wiadomości o prawdach wiary i historii narodu wybranego, lecz dostarczal mu takze wzorów i wskazań moralmo-ascetycznych, od pocz̨tku wychowywał 1 kształtował duszę dziecka. Znajomość Pisma św. miała umoźliwié dziewczynce przygotowywanej do żcia zakonnego wewnętrzne zjednoczenie z Chrystusem - jej duchowym oblubieńcem 50 .

Proponując program studium Pisma św. dla arystokratycznej uczennicy, Hieronim przestrzega, by nie dawano jej do ragk żadnych apokryfów ze względu na mogące się w nich kryć błędy dogmatyczno, ponieważ "szukanie złota w błocie wielkiej wymaga roztropności". Jeżeli zaś zechciałaby je czytać, niech to czynl z rozwaga woszukiwanlu jedynie pi gknego stylu i formy, a nie dogmatycznej treści, pomna "że nie są one dziełani tych, których imiona noszą w tytułach"51. Trudno powiedzieć, co Uczony rozumial w tym miejscu przez apokryfy: czy tylko apokryfy biblijne, czy tez dzieła podstawiane podczas ówczesnych polemik doktrynalnych pod nazwiska wybitniej-

mị wzbogaci 1 zdebkęswego serca, niech przekazuje pamięci Proroków, Pięcioksiłg, Księgi Królewskie, Księgi Kronik, Księgi Ezdrasza 1 Estery. Na koniec dopiero moze się zapoznać z Pieśnia nad Pieśniami bez obawy, że nie zrozumie w jej słowach duchowego sensu tego epitalamium, które mogłoby ją zranić, gdyby od niego zaczęła".

19 Ad Gaudentium 4, CSEL 56,160, Czuj t.3,290: "Niech się uczy na pamięć Psałterza i aź do lat dojrzalych niech czynt skarbem swego serca Ksiegi Salomona, Ewangelię, Apostołów i Proroków".

50 Ad Laetam 7, CSEL 55,298, Czuj t.2,408: "Niech jej nigdy nie znajdują gdzie indziej, jeno w światyni. Pisma, dowiadujaç się od Proroków i Apostołów o duchowym małzeństwie".

i1 Tamze 12, CSEL 55,303, Czuj t.2,412. 
szych autorow ortodoksji, celem przemycenta pewnych błedów teologicznych. Wydaje oie, ze wre wchodzilo jedno 1 drugie.

Obok Blblil Hieronim zalecal dzlewczynce lekture pism nieco weześniejszych autorów chrześcijańskich: św. Cypriana $/+258 /$, św. Atanazego Aleksandryjskiego $/+379 / 1$ św. Hillarego z Poitiers $/+367 / 52$, które obok treśc1 ascetycznych, miały ja umocnić wierze. Widzimy móród nich autora piszącego po grecku/Atanazego/, co suponuje pózniejszy iek dziewczynki. 1 znajomość tego jezyka. Nie wiemy, o jakie plsma tu chodzi, ale możemy przypuszczać, źe ma na myśli dzieła ascetyczne poświecone dzlewictwu, na co zdaje się wskazymać list do Eustoch11 ${ }^{53}$. Zarówno bowiem Cyprian ${ }^{54}$, Jak 1 Atanazy, pisali wprost - dziewictmie, Hilary zaś bezpośrednio tego nie czynit, ale Hieronín mógl mieć na myśli przypisywane mu dzleła na ten temat ${ }^{56}$. Wszyscy c1 trzej autorzy byl1 prześladowant za wiare 1 stanowili doskonały przykład mocnej 1 zywej wiary. Dz1w1 nas nieco brak propozycj1 lektury pism o dziewictwie Tertuliana, Ambrozego 1 Damazego, którezalecal Eustoch11 57 .

52 Tamze 12, CSEL 55,303, CzuJ t.2,412.

53 Epistola 22,22/Ad Eustoch1um/, CSEL 54, 174-175, Czuj t.1,135: "Jesil zá́ chcesz wiedzlec, od llu przykroáci wolna jest dz1ew 1ca, a ilo uwikłana zona, czytaj rozprawe Tertuliana do przyjaciela fllozofa i inne o dziewlctwie, 1 znakomita ksiazke błogosławlonego Cypriana, 1 poswięcono temu tematow 1 dzieła papieza Damazego mierszem 1 proza ułozone, oraz dziekka naszego Ambrozego. któro niedawno napisaz do siostry".

54 Por. De habitu virginum, CSEL 3,1, 185-205, POK 19, 135-156.

55 Epistola ad Dracontium, $P G$ 25, 523-534; Ep1stola ad Amun, PG 26, 1169-1176; zachowane tylko wersji syryjskiej: Sermo de virginitate, "Museon" 40/1927/209-226; Epistolà ad virgines, "Museon" 41/1928/169-216; zachowane w wersji koptyjskiej: Epistola ad v1rgines, CSC0 150, 73-99 = "Museon" 42/1929/ 197-264; Praecepta ad v1rgines, $\operatorname{CsC} 0150,99-100=\mathrm{AB} 67 / 1949 / 142-152$; Tractatus acephalus de virginitate, $\operatorname{CSCO} 150,101-106$; Epistola de caritate et temperantia, $\operatorname{CSCO} 150,110-120=$ "Museon" 40/1927/ 265-292.

56 Hieronim czesto $w$ swoich listach wspominal pisma polemiczne 1 egzegetyczne św.Hilarego zalecajac je czytać, szczególnie peren ascetycznych wskazań Tractatus in Psalmos; por. Epistola 34,3/Ad Marcellain CSEL 54,261, CzuJ t.1,200: "Dziwie siz, żeś w komentarzach Hilarego nie czytała"; Epistola 70,5 /Ad Magnum/, CSEL 54, 7.07, Czuj t.2,125: "Hilary, wyznawca i biskup zyjacy w moich czasach, pod względem stylu i ilości ksiagg naśladowat dwanaście ksiag Kwintyliana"; fragmenty przypisywanych mu dziel ascetycznych: De spiritali prato, PLS 1,286; De balteo castitais, PLS 1,286. Por. note 53. Tertullianus, De exhortatione castitatis 1 De 
kanon lektur dla dziccka winien polleyać selekcji puzez wychowawców, by dostarczał właścirycil przykłalów i przynosil dobre owoce a nie szkodę. "Innych zaś autorów noże czytać tak, żeby raczej wydawała o nich sad, niż szła wiciı ślaly" 58 . Nie wiemy, co rozumiax przez wyrażenie "innych autorów", czy tylko dzieła chrześcijańskie czy także pisma autorów pogańsich, którycí sam wiele cytował, ale nigdzie imiennie nie zalecal młodziezy. Co więcej, Hieronim zachęca, aby dorastajłzca dziewczynka przeznaczona do zakonu codziennie czytała nie tylko pismo św. i ksiazzki religijne, ale również samodzielnie opracowywała na ich podstawie pewne zadania, które kształciłyby jej duszę:

"Niech couziennie ourabia pewne zadanie z Pisma św"59 "Ustal przez lle godzin powinnaś uczyć się Pisma św. i przez jaki czas czytać nie dla pracy, lecz dla przyjemności i ksctałcenia duszy" 60 .

Crytanie i studiowanie winno być codziennym chlebem dorastającej dziewczynki. Umiłowanie Bożych ksiag nie tylko zastapi jej skłonność do strojów, ale zapewni erudycję i poprawną interpunkcję ${ }^{61}$. Wydaje sie, ze nakreślony progran przerastał siły dorastajzcego dziecka 1 należało go rozciągnąć na okres szkoły średniej 1 wyższej.

Z innych dyscyplin nauczanych wówczas w szkole $i$ w domu była muzyka.Hieronım, jak większość pisarzy wczesnochrześcijańskich, by zdecydowanym przeciwnikiem wszelkiej muzyki instrumentalnej. Tego rodzaju muzyka, będąc nieodłącznym składnikiem ofiar pogańskich oraz niemoralnych mimicznych 1 pantomimicznych przedstawien teatralnych, uchodziła za synonim zepsucia moralnego62. Nic więc dziwnego, że chciał uchronié przed jej zgubnym czarem mała dziewczynkę pisząc: "Niech będzie głucha na instrumenty muzyczne,

virgintbus velandis, CCL 2,1015-1035 1 1209-1226; Ambrosius, De virginibus /do swojej siostry Marcoliny/, PL 16, 187-232; De virginitate, PL 16, 265-302; Exhortatio virginitatis, PL 16, 355-364.

58 Ad Laetam 12, CSEL 55, 303, Czuj t.2,412.

59 Tamże 9, CSEL 55,300, Czuj t.2,409.

60 Epistola 130,15 , CSEL 56,195, Czuj t.3,323/do 16-18 letniej Demetri1/.

61 Ad Laetam 12, CSLL 55,302, Czuj t.2,411.

62 Obszerniej na ten temat por. S.Longosz, Muzyka w ocenie wczesnochrześcijańskich pisarzy, "Musica Ant1qua" 6/1982/ 353-388. 
niech nie wie, w jakim celu uczyniony jest plet, lira i cytra63.

W okresie szkolnym Hieronim proponował nadal uczyć dorastaJaç dz dewczynkę prac ręcznych, ale o wyższej skali trudności:

"Niech się także uczy przazść wełnę, trzymać kądziel, kłaść na kolanach koszyk"64.

Warto pamiętać, ze zalecenia te podawał patrycjuszkom, przypominając niejako, że 1 na nich spoczywa obowiazzek pracy, by nie miały czasu myśleć o rzeczach błahych 1 niegodziwych. Wskazywał równiez na użyteczność znajomości rachunków niezbędnych do należytego zarzadzania gospodarstwem domowym 65 .

Asceta ze Strydonu nie występowal z propozycja odbywania przez dzlewczęta studiów wyższych ani téz nie zalecał podrózy w celu ich pogłębienta. Jedno i drugle uwaźa bowiem za stosowne jedynie dla młodzieńców 66 .

\section{Wychowante moralno-ascetyczne}

Rodzlce, wychowawcy $i$ nauczyciele wychowaniu domowym mieli, zdaniem Hieronima, zapewnić dziewczynce nie tylko wiedzę, ale równiez formację moralno-ascetyczną. Problem ten uwzględniał, jak wyżej wskazano, sam kanon lektur odpowiednio dobranych i podanych dziecku w należytym czasie. Jezel1 do ascezy 1 pewnego pozlomu moralnego zobowiązuje juz sama przynależność do chrześcijaństwa, to tym bardz1ej przeznaczenie do zakonu, bo "laska taka winna pociagać za soba odpowiedni trud"67. Trud zaś ten nad nalezytym profilem moralnoascetycznym dziecka będzie myrazal sie - zdaniem Hieronima - prze-

63 Ad Laetam 8, CSEL 55;299, Czuj t.2,409; por. Epistola 54,13, CSEL 54,479, Czuj t.1,376: "Spiewaka nalezy pędz1ć jako szkodnika, lutnistón 1 cytrzystki oraz wszelk1 tego rodzaju diabelski chór, jakby śmiercionośne pieśnt syron, wyganiaj precz z zabudowan swolch".

64 Ad Laetam 10, CSEL 55,300, Czuj t.2.410.

65 Por. Epistola 71,3, CSEL 55,4, Czuj t.2,129.

66 Zarówno o studiach wyższych w ogóle/Eplstola 53,6/, jak 1 o podróżach poszukiwaniu wiedzy /Epistola 125,6/ mspomina tylko okolicznościowo.

67. Ad Laetam 8, CSEL 55,299, Czuj t.2,409. 
strzeganiu określonych zakazóm lub nakazów, którew ogóle miały uchronić ją przed zopsuciem moralnym. Hieronim jako realista jest świadom, ze warunkiem ukształtowanta moralno-ascetycznego profilu dziewczynki jest zdrowie fizyczne. Dlatego zwraca uwage na należyte odzywianie i odpowiednią higienę. Chociaż sam, jako surony asceta, zachecał innych do postów 1 wyrzeczeń, a dziociom tym wieku zalecat pewien umiar co do llości l jakości pokarmów, to jednak przestrzegat przed zbytnia surowościa w przeciwieństwio do ntektórych przepisów zydowskich, bramińskich czy egipskich:

\begin{abstract}
"Przed dojściem do dojrzacosci niebezpleczna jest dla młodych ludzi cięzka wstrzemięźlimośc68/.../ Nie podobaja mi sie, przede wszystkim w modym wieku, długie i nieumiarkowane posty, przeciagajace się godnie, kiedy to unika sie oliwy w pokarmie 1 owocór. Przekonałem sie z doświadczenia, ze gdy osiołek zmęczy się wrodze, szuka odpoczynku./.../W ciłgłym poście należy trzymać sie zasady, by w długiej podrózy, stale były podtrzymywane siły, abyśmy wóród biegu nie padii na pierwszym postoju"69.
\end{abstract}

Mimo lz pisze do nychowawców z rzymskich domów, gdzie posiłki były obficie zakrapiane winem przestrzega, by dziecka, a tym bardziej dziewczynki przeznaczonej do dziewictwa, nie przyzwyczajac do plcia wina ${ }^{70}$. Ze względu jednak na zdrowie 1 spożywane w tym reglonie pokarmy pozwala w wyjatkowych okolicznosiciach, nawet małej dzlewczynce na jego spożywanie w niewielkich ilościach, tak jak onglś zezwalał Tymoteuszowi św. Pawel /1 Tym 5,23/:

\footnotetext{
"Jeśli wymagá będzie potrzeba /.../ niech 1 wina po trochu uźywa ze względu na zołądek, a także 1 spozywantem miesa niech się pokrzepia, by nogi
}

68 Tamże, Czuj t.2,408.

69 Tamze 10, CSEL 55,301, Czuj t.2,410; obszerniej o proponowanych przez Hieronima posiłkach por. Epistola 54, 9-10, CSEL 54, 474477, Czuj t.1, 373-375.

70 Tamże 8, CSEL 55,299, Czuj t.2,408: "Już teraz niech s1ę uczy nle pić wina, w którym tkwi rozpusta"/EP 5,18/; Epistoia 22,8, CSEL 54,154, Czuj t.1,118: "Na to przede wozystkim zwracam uwage 1 usilnie prosze, by oblubienica Chrystusa unikata wina jak trucizny. Wino to pierwsza broń w reku szatana przeciw młodości. /... Wino 1 młodość to dwa źródıa pożdliwosci!" 
nie odmówiły posłuszeństwa, zanim zaczną biegać"71.

Zaleca jodnak, by nie dopuszczać dziecka do wspólnych, uroczystych biesiad, zabaw i wesel domowych:

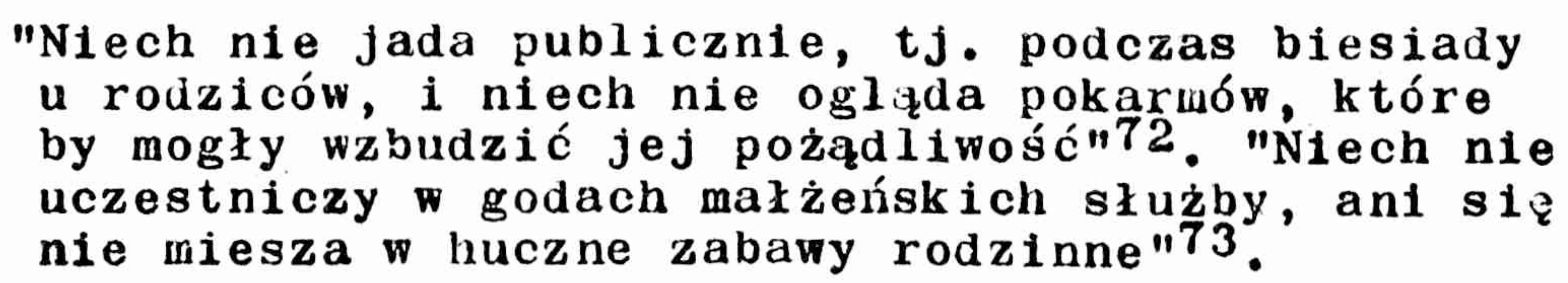

Ciało dziecka, by było zurowe, wymaga również odpowiedniej higieny. Ludzie starożytni od małego przyzwyczajeni byli do częstego korzystania z laźni publicznych lub domowych, gazie spędzali wiele czasu na wspólnych kąplelach. Hieronim nie pomija tego aspektu 1 przed osiagnięciem dojrzałości /ante annos robustiae aetatis/ pozwala dziewczynce uczęszczać do łaźni ${ }^{74}$. Zabrania natomiast wspólnej kąpiel1 z innymi, ze względu na wyrabiante u niej postawy wrodzonej skromności ${ }^{75}$.

Hieronim zna dobrze naturalnaz skłonność kobiet do ozdób i strojów, dlatego przestrzega matkę, by nie hołdowała dziewczęcej próz-

71 Ad Laetam 8, CSEL 55,299, Czuj t.2, 408-409; por. Epistola 22,8, CSEL 54,154, Czuj t.1,118-119: "Patrz, z jakich to przyczyn zezwala Apostoł na picie wina: w wyadku cierpienia zołazka i czestego niedomagania. I byśmy się przypadkiem nie zasłania$1 i$ chorobani, polec1ł po trochu używać wina, udzielając rady raczej jako lekarz niz Apostoł, chociaz 1 Apostol jest lekarzem duchowyu".

72 Ad Laetam 8, CSEL 55,299, Czuj t.2,408.

73 Tamze 11, CSEL, 55,302, Czuj t.2,411.

74 Tamze 8, CSEL 55,299, Czuj t.2,408: "A do tego czasu, jeśl1 wymagać bedzie potrzeba, niech 1 do łaźn1 chadza".

75 Tamże 11, CSEL 55,302, Czuj t.2,411: "Wiem,że niektórzy przykazal1, by się dziewica Chrystusowa nie myła razem z eunuchami ani z niewiastami zamz̨źnymi/.../Mnie się w ogóle nie podoba mycie u dziewicy dorosłej, która winna wstydzić się siebie samej 1 nie moźe widzié się naga. Jeśli bowiel umartwia swe ciało czuwaniami 1 postami, /.../ to dlaczego z drugiej strony ma wznlecać goracej taźni uśpione ognie?". 


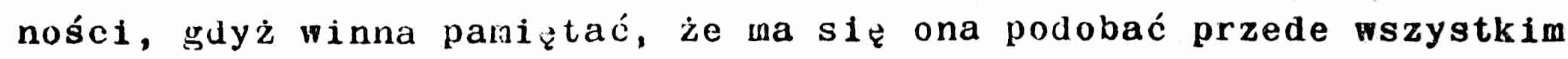
Chrystus owi :
"Niech strój i odzienie wskazuje jej, komu została przyobiecana. Nie przekłuwaj jej uszu, nie maluj szminkaz i purpuriz ust poświęconych Chrystusowi, nie gnieć szyi perłani i złotem"76.

Dziesiąć lat później IIieronien zdobył się na większą tolerancję, a mianowicie, był zdania, że nawet dziewczat przeznaczonych do dzlewictwa, nie należy ubierać w ciemne szaty 1 nie pozbawiać wszelkich ozdób, aby później rezygnowały z nich dobrowolnie i świzdomie -

"I lepiej jest, by nasyciwszy sie gardziła, niż nie majac pragnęła mieć"77.

lecz zachęcał, by od najwcześniejszych lat uczyć dziewczynkę pogardy dla wykwintnych strojów:
"Niech gardzi jedwabiem, wełnà Serów 1 złotem w blaszki wyci zgniętym. Niech sposobi szaty takie, które chronta przed zimnem, a nie takie, które obnażaja odziane cia- $10 " 78$.

IIIeronim zdaje sobie sprawe, ze do pełnego rozwoju dziecka potrzeba mu towarzystwa jego rówieśników ${ }^{79}$. Przestrzega jednak

76 Tamze 5, CSEL 55,296, Czuj t.2, 405-406; por. Joannes Chrysostomus, De inani gloria 17, SCh 188,100, PSP 13,163: "Jeśl1 dziewczyna przyzwyczaiła się pokoju matczynym do kobiecych ozdób, po opuszczentu domu stale będzie przykra dla męża i spomoduje mu więcej kłopotów niź poborcy podatków".

77 Ad Gaudentium 2, CSEL 56, 157-158, Czuj t.3,287.

78 Ad Laetam 10, CSEL 55, 300-301, Czuj t.2,410.

79 Ad Gaudentium 4, CSEL 56,160, Czuj t.3,290: "Niech kobieta przebywa w towarzystwie kobiet, niech nie zna, co więcej, niech się boi zabaw z chłopcami"; Ad Laetam 9, CSEL 55,300, Czuj t.2, 409-410: "Niech znajduje upodobanie nie $w$ pieknie uczesanej i szlachetnie urodzonej towarzyszce, co dzwięcznym głosem umie zaśplewać miła plosenke, lecz wowaznej, bladej, zaniedbanej, smutnej". 
zdecydowanie przed towarzystwem kolezanek zmanierowanych, które zajma jej wiele czasu i naucza wiele zła, a jeszcze bardzlej przed towarzystwem światowych chłopców, którzy pochlebstwami 1 upominkami nie tylko moga wyrządzić szkodę 1 zamieszante w duszy dorastającej dziewczynki, ale równiez obudzić wiej śpiąca jeszcze naturę:

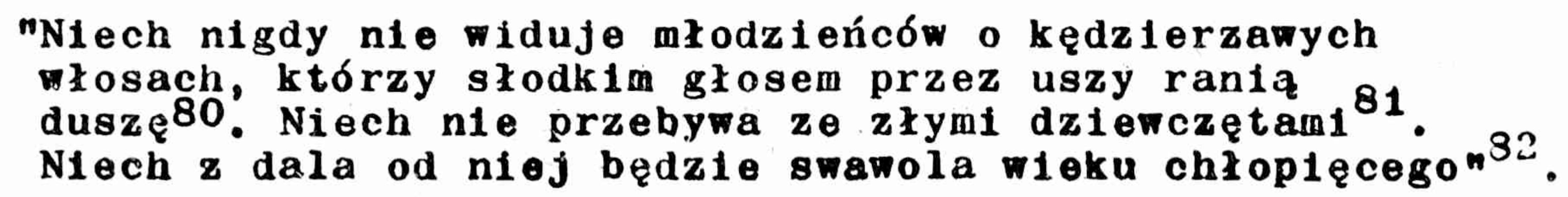

Dziewczynke nalezy zwaszcza chronic przed zgubnymi wpływami kłamstwa 1 nieskromnych słów, nałogów 1 nawyków, których musiałaby sie w pózniejszym wieku wstydzić. Wiele bowiem rzeczy moźe uchodzić na pozór za dobre i cnotliwe, a faktycznie kryje w sobie zło, które trzeba umieć rozpoznawać:
"Niech sio uczy nie słuchać nic innego, nic innego nie mówlé, tylko to, co należy do bojaźni Bożej. Niech nie rozumle brzydkich słów83. Niech nie zna zadnego nieskromnego słowa, a jeśli przypadkiem zgiełku, wíród rozbieganych domowników usłyszy coś takiego, niech nie rozumie" 84 .

Według Hieronima do osiagniecia religijnego i moralnego wychowania nie wystarczaja tylko nakazy 1 zakazy rodziców i wychowawców, ale potrzebna jest pomoc nadprzyrodzona - modlitwa, kościól 1 sakramonty św.

Do modlitwy, jak wiemy, zachęcał już od lat najwcześniejszych. Jako formuly modlitewne zalecal psalmy nawet dla dzieci nio umiejacych czytać 1 pisać ${ }^{85}$. W późniejszym wieku, mając na uwadze dziewczynkę

80 Ad Gaudent1um 4, CSEL 56,160, Czuj t.3,291; por. Ad Laetam 9, CSEL 55,300, Czuj t.2,409: "Niech się nie uśmiecha do niej zaden pięknie uczesany młodzieniec".

81. Ad Laetam 11, CSEL 55,302, Czuj t.2,411.

8c Tamze 4, CSkL 55,294, Czuj t.2,403.

83 Tamze 4, CSEL 55, 293-294, Czuj t.2,403.

84 Ad Gaudentium 4, CSEL 56,160, Czuj t.3,290.

85 Ad Laetam 4, CSEL 55,294, Czuj t.2,403. 
przygotowywang do zakonu, zalecal matce 1 opiekunce przyzwyczajac ja do porządku modlitw ówczesnych klasztorów zeńskich ${ }^{86}$, wraz z nocnymi czuwantami, śpiewem hymnów, czytaniami 1 kilkakrotnym wstawaniem do modlitwy na wzór godzin kanonicznych ${ }^{87}$. Dz1w1 nas, jak moźna było tak wielce przepełniony program kilkugodzinnymi modlitwami i czumaniami nocnymi, trudny do wypełnienia nawet dla osoby dorosłej, proponować kilkunastoletniemu dziecku. Hieronim okazuje się tu zbyt surowym asceta, stawiajacym mało realne wymogi. K1erowała nim jednak gorliwośe, by całkowicie poświęcić Bogu małą dziewczynkę. Obok modlitw odmawianych już na sposób zakonny womu, dziewczynka winna chodzić tylko razem z matka lub oplekunka na modlitwy i nocne czuwanie do kościoła 1 rzymskich bazylik męczenników:

"Gdy zacznie dorastać 1 za przykładem Oblubieńca swego wzrastać w mądrości, w latach i kasce u Boga i u ludzi, niech śpieszy z rodzicami do świątyni prawdziwego ojca, ale ze światyni niech z nimi nie wychodzin88.

86 Epistola 22,37/Ad Eustochium/, CSEL 54,201, Czuj t.1, 154-155: "Powinniśmy mieć ustalone godziny modlitwy, aby - jeślibyśmy byli przypadkiem jakłsś praca zajęci - sam czas wzywał nas do tego obowi tzku. Kazdy zna doskonale czas godziny trzeciej, szóstej, dzlewiłtej, a takźe jutrzni i nieszporów. Nie przyjmuje się pokarmu bez uprzedniej modlitwy, ani nie odchodzi się od stołu bez dzi ákczynienia Stwórcy. W nocy dwa albo trzy razy naleźy wstawać 1 rozważać to, co utkwiło wanięci z Pisina śn. Wychodzazcych wościnę ma uzbrajać modlitwa, powracającya do domu niech ona zabiega droge ... Przed wszelka czynnościz, przed każdym krokiem niech ręka czyni znak krzyza"; por. Epistola 130,15, CSEL 56,195, Czuj t.3,323: "Oprócz kolejnego odmawiania Psalmów i modlitw, co powinnaś wykonywać zawsze o godzinie trzeciej, szóstej, 'dziewiztej, wieczoren, o północy i rano.".

87 Ad Laetam 9, CSEL 55,300, Czuj t.2,410: "żeby /opiekunka/ ją uczyła i przyliładen przyzwyczajała do modlitwy i wstawania wocy dla odinawiania Psalmów, do śnierrania rano hymnów, do stawania w szeregu o godzinie trzeciej, szóstej, dziewiątej, jak przystoi wojowniczce Chrystusowej, i do składania ofiary wieczornej przy zapalonej świeczce. Niech tak przechodzi dzień, przy takim zajęciu niech ja noc zastaje. Po nodlitwie powinno następować czytanie, po czytaniu modlitwa. Krótki bądzie sį zdawał czas, tak różnorodnyıi wypełniony czynnościami"/.../ by "zaraz po jedzeniu mogła czytać, modlić sił, śpiewać Psalmy".

88 Tamże 7, CSEL 55,298, Czuj t.2,407-408. 
Zastanawlać może fakt, ze Hieronim mówląc o wychowaniu dzieci, nie proponuje nigdzie żadnych środków sakramentalnych, jak spowiedź, komunia św., czy uczestn1ctwo we mszy św., o których tak wiele uczy dzisiejsza pedagogika katolicka. otóz, chociaz w swych listach poświadcza zarówno codzienne odprawianie mszy św., jak 1 zwyczaj codziennej komunii, szczególnie na terenie Rzymu ${ }^{89}$, to jednak wego czasach nie zalecano ich jeszcze jako zbawiennych środkón wychowawczych ${ }^{90}$. Ich oddziaływanie miała zastąpić religijna atmosfera rodziny chrześcijańskiej.

Pedagogiczne uwagl Hieronima, dotyczace początkowego wychowywania chrześcijańskich dziewcząt z przełomu IV i v wieku, nie stanowia jakiejó pełnej psychologicznej teorii lub nauki o wychowaniu czy kształceniu dzieci, ale zbiór luźnych uwag, które tylko w szerszym sensie można nazwać wczesnochrześcijańska pedagogika. Mimo, ze sam zreszta Hieronim uwazal je za drobne, nie trzeba ich lekcemazy ${ }^{91}$. Wskazują one na Hieronima praktyka, który zdąza do celu z argumentacją, zaczerpniętą z Pisma św. i zasad moralnośc1 chrześcijańskiej.

H dziedzinie wychowania intelektualnego jego ogromną zasługa jest próba wykorzystania i dostosowania programu 1 porządku kształcen1a,praktykowanego od wieków w państwie rzymskim w oparciu o podręcznik Kwintyliana, do potrzeb chrześcijańskiego wychowania. Z wielowiekowej rzymskiej praktyki przeją tylko te elementy, które uznał za niezbędne dla chrześcijańskiego dziecka. Zalecał bezpośredni kontakt dzlecka z Plsmem św. pod kierunkiem rodziców i wychowawców. Rzecz clekawa, ze Hieronim, wybitny teolog 1 egzegeta mimo systematycznego rozłozenia lektur ksiąg biblijnych

89 Por. Ep1stola 120,2, CSEL 55,479, Czuj t.3,121; Epistola 71,6, CSEL 55,6, Czuj t.2,131-132; Ep1stola 21, 26-27, CSEL 54,129, Czuj t.1,99; Eprstola 49,15, CSEL 54,377, Czuj t.1,297; J.Czuj, Swięty Hieronim, Zywot-dziela-charakterystyka, Warszawa 1954, 141-144.

90 Por. J.Brunner, Der hl.H1eronymus und Madchenerzielung, dz.cyt., 39; nie wepominaj równiez o takich srodkach wychowawczych 0jcowie Kapadoccy/por. K. Weiss, Die Erziehungslehre der drei Kappadozier, Freiburg 1903/, ani św.Augústyn.

91 Ad Gaudentium 3, CSEL 56,159, Czuj t.3,289; Ad Laetam 4, CSEL 55,295 , Czuj t.2,404. 
dla dorastającej dzlemczynk1 nie pomyślał o prostym, skrótonym podręczniku dostosowanym do mentalnośc1 dziecka, odpowiedniku naszej biblijkiczy popularnego katechizmu. 0 tym jednak nikt tym czasie jeszcze nie myślał. Hównieź nieco wcześniejszy od omawianych listów, bo powstały w 399 r., traktat św.Augustyna "De catechisandis rudibus" nie był przeznaczony dla dzleci lub młodziezy, ale dla ludzi dojriatych mających juz pewne przygotowanie filozoficzne. Pewne szklce katechez biblijnych dla dzleci pozostawiz w ty czasie na Wschodzie ś⿴.Jan Chryzostom ${ }^{92}$. Dla ogółu dorosłych chrześcijan źródłem poznania objawienia Bożego były homilie 1 kazanła mgłaszane podczas słuzby liturgicznej oraz istniejace komentarze biblijne, dla dzieci zaś pozostawał tylko dom 1 rodzina93.

I Jak dzieła Homera 1 Wergiliusza w rękach dzieci pogáskich były elementarzem dla rozwoju Intelektualnego, tak Biblia dla dzieci chrześcijańskich była podstawa dla formacji religijno-moralnej. ram przygotowywano obywatela rzymskiego, tu człowieka Kościoła 1 chrześcijanina.

Uderzająco duźa liczba nakazów 1 zakazów Hieronima, dotyczacych higieny, pokariów, towarzystwa i zycia dziewcząt przeznaczonych do klasztoru, moze sprawić wrażenie, iz ich dzleciństwo było bardzo smutne 1 ponure. otóz Pedagog z Betlejew z jednej strony pragnął ustrzec je za wszelka cenę przed upadkiem moralnym i rozpustą szorzonaz wówczas przez teatr, laźnie, muzykę, tańce i życie towarzyskie ${ }^{94}$, z drugiej zaś przygotować je jak najlepiej przez surowi ascezę do stanu dzlewiczego:

92 De inani gloria 39-46, $\operatorname{SCh} 188,130-145, \operatorname{PSP} 13,169-175$.

93 J.Brunner, Der hl. Hieronymus und Madchenerziehune, dz.cyt., 41.

94 O ówczesnym zepsuciu moralnyw w izymie, por. L. Friedlmer. Die Darstellungen aus der Sittengeschichte, 10 Auplage, $B$ C. 1 , Leipzig 1922, 267-317/= Die Frauen/. 
"niech nie zna świata; niech żyje anielsko, niech będzie ciele bez ciała, niech cały rodzaj ludzki uznaje za podobny do niej"95.

Zdawał soble również doskonale sprawz̨ z trudności zrealizowania swoich rad i zaleceń, dlatego rodzicom świadomym niewywizzania się z tych obowiązków wychowawczych polecał jak najszybciej oddać dziecko do klasztoru 96 .

Dzięki tym dwom listom poświ zconym wychowywaniu dziewcząt Hieronim, znany asceta 1 biblista, wszedł również jako wychowawca do historil wczesnochrześcijańskiej pedagogiki ${ }^{97}$. Listy te nie tylko saz wspaniałym dokumentem i świadectwem trosk1 pierwszych chrześcijan o religijne wychowante dzieci, zwłaszcza dziewcząt, ale równieź długo w średniowieczu były zalecanz przez synody podstawą pedagogiki w przyklasztornych szkołach dla dziewcząt 98 . Proponowana przez nie lektura duchowa miała chronić także same zakonnice przed zbytnim zamknięciem się w ascezie i otwierać im drogę do

95 Ad Laetam 13, CSEL 55,303, Czuj t.2,412.

96 Ad Laetam 13, CSEL 55, 303-301, Czuj t.2, 412-413: "Odpowiesz: W jaki sposób ja, kobieta świecka, wakim tłumie ludzi świeckich moge przestrzegać tego wszystkiego?" Jeśli tak, to nie podejmuj tego cięzaru, którego nie mozesz dźwigać. /.../ oddaj najkosztowniejszy klejnot izdebce Maryi i złó w kołysce kwilacego Jezusa. Niech sie chowa w klasztorze, niech przebywa wóród dziewiczych chórów".

97 Por. S.Kot, Historia wychowania, t.1: Od starożytnej Grecji do połowy XVIII w., Lwów $1934^{2}, 113-115$; J.H.Marrou, H1stor 1 a wychowania w starożytności, Warszawa 1969,443-444, 454-458; Historia wychowania pod red. L.Kurdybachy, t.1, Warszawa 1965, 155-156; F. Eby - Ch.Flinn Arrowood, The history and philosophy of education ancient and medieval, Englewood Cliffs 1963, 648650; Erziehung und Bildung in der heidnischen und christichen Antike, red. Th.J.Horst, Darmstadt 1976, 522-526.

98 Synod $w$ Akwizgrante z 817 r.w drugiej części dokumentu "De institutione sanctimonialium" irp 1-6,22/ nie tylko zawiera. list Hieronima do Lety, ale zaleca go przeoryszom wykorzystywać przy pychowywaniu dzlewczat do klasztoru, por. J.C.Hefele H.Leclercq, IIIstoire des conciles, IV, 1, Paris 1911, 14-16; D. Gardiner, English Girlhond at school, oxford 1929, 4-8; F.Pby - Ch.Flinn Arrowood, The history and philosopliy of education, dz.cyt., 650 . 
rozwoju intel ektualnego 99

Wartość pedagogiki Hierontma polega niewatpliwio na przejęciu najlepszych metod ówczesnego nauczania szkolnego chłopców, uwzględniajacych ćw1czenie panięci i kojarzenia, z wykorzystaniem zasady poglizdowości i zastosomaniem ich po raz pierwszy do domowego ksztaicenia dziewczłt. Do innych jego zasług nalezy wprowadzenie juz w poczłtiowej fazie nauczania treści chrześcijańskich oraz podkreślenie psychicznym rozwoju dziecka roli pieszczot i czułości ze strony rodziców i najbliższej rodziny.

Wyliczony jednak przez Hieronima kanon lektur z Pisma św. 1 pisarzy chrześcijańskich wydaje sig zbyt obszerny i trudny do przyswojenia dla dorastajacej dziewczynki. Nalezy tu jednak wyrazić wdzięczność św.Ilieronimowi, że juź 15 wieków temu uznał "nieprzeciętną" chłonność 1ntelektu kobiet.

\section{Alicja Stępnlewska - Lublin}

Éducation familiale des Filles dans la pédagogie de saint JÉrôme /Résumé/

L'article qui se compose de trois parties, s'occupe des remarques pédagogiques de saint-Jérôme concernant 1 éducation primaire de filies a la base surtout de ses deux lettres: "Ad Laetam"/ep. 107/ et "Ad Gaudentium"/ep. 128/. Dans la premiere partie sous le titre: "Les educateurs" 1 'auteur traite les qualifications morales-intellectuel les que doivent posséder d'aprés Jérôme, tous les éducateurs de 1 enfant à la maison: bonnes d'enfants, protectrices, instituteurs, grands-parents et surtout les parents. Ce sont: $1^{\circ}$ àge convenable, bons moeurs, vie religieuse de modèle, donner un bon exemple, éducation intellectuelle suffisante et une grande dose d affection. Dans la deuxieme partie intitulée: "Vie intellectuelle" l'auteur divise \%education de la pille en deux périodes: jusqu' à la septième année de la vie et de 7 a 15 an de la vie. Déja dans la 1-ere période Saint Jérome propose de lire et d'écrired'apres les textes bibliques et le psqutier ainsi qu'après de petits travaux manuels étant plutôt un amusement. Dans. la deuxième période étant celle de l'école elémentaire romaine,l'Ascète de Bethlejem sans recorbander, aux filles l'école publique,proposait outre la continuation de l'étude du grec et du latin, suxtout la lecture de la Bible en adeptant ses certains livres \%chapitres/a lage de 1 enfant et la lecture des oeuvres de plus eminents auteurs du début du christianisme/St.Cyprien, St.Athanase, St.Hilaire/. En outre 11 encourage à continuer

99 S.Kot, Historia wychowania, dz.cyt., 115. 
l'étude du psautier et des travaux manuels des remmes. Saint Hilaire a pris la division en deux périodes ci-dessus comme et plusieurs remarques sur le sujet de 1 education intellectuelle de "Institutio oratoria" de Quintilien. Enfin dans la troisieme partie sous le titre: "Education morale-ascétique", 1 auteur traite d'abord les propositions de Jéróme concernant le corps et ensuite 1 âme et 1 éducation religieuse. L'ascéte de Bethlejem commendait de ne pas obliger 1 'enfant aux jeûnes, ne le pas prendre aux banquets solennels avec les adultes, garder une modération en habits, garder devant une mauvaise compagnie, ne pas permettre de sortir seul aux endroits publiques même aux eglises, garder devant le vulgaire, yocabulaire des serviteurs et de domestiques. S' 11 . s'agit de 1 éducation religieuse, il encourageait à habituer tôt $l$ 'enfant aux prieres quotidiennes même d'après modèle des neures canoniques, à chanter les Psaumes, à prendre part souvent aux offiçes d’église et à donner un modèle parfalt de la vie religieuse. Grâce aux remarques ci-dessus, Jérome traitant, comme unique auteur de 1 ancienne Église si détailleusement la premiére éducation des filles, occupe une importante place dans la pédagogie du début du christianisme. 